\title{
Prosecution and Protection from a Gender Perspective In Trafficking of Women
}

\author{
PHD Candidate Ariana Qosaj-Mustafa
}

\author{
Prof. Dr. Netkova Bistra
}

\begin{abstract}
This article examines trafficking in women from a human rights perspective and through the gender based lenses. Thus it concludes that prosecution and protection as preconditions for successful fight against trafficking in women lies on enacting of laws that are in line with international standards, implementation of those and successful prosecution of traffickers. Furthermore, it points out that protection of victims is an important and integral part of the process of prosecution of traffickers and that it should be based on human rights principles as stipulated in international legal instruments and jurisprudence.
\end{abstract}

\section{INTRODUCTION}

The fight against trafficking in women, as a complex phenomenon, has been difficult but dynamic. It involves responses on international, regional, and national levels. There have been a number of strategies and policies targeting trafficking in women, adopted and implemented world globally, in order to eradicate this practice.

Despite these efforts trafficking still exists and is a growing phenomenon. This situation raises questions of how effective the already existing strategies to combat trafficking are and what should be done to improve them. To that end, this paper will elaborate the issue of what can be done in order to enhance the effectiveness of the fight and eradication of trafficking in women by exploring the issue of policies on prosecution and protection through the human rights perspective.

Combating trafficking in persons, more specifically women, from a human rights approach, raises a number of issues that will be discussed in the text below. With respect to prosecution there are procedural and evidentiary issues, rights of victims to pursue civil actions ${ }^{1}$ and compensation for victims; ${ }^{2}$ with respect to protection and assistance there are issues of shelters for women victims of trafficking, residence permits, and witness protection.

\footnotetext{
${ }^{1}$ Highly interesting and also useful as a reference point in fighting the problems of trafficking in women and forced prostitution thereof, in cases where the government can or will not, is the Civil RICO. According to which: 'it allows a private cause of action for anyone injured by the investments in, acquisition or operation of and enterprise that affects interstate or foreign commerce through a 'pattern of racketeering activity' occurring with in a ten year period. Racketeering is defined as the violation of state and federal offences listed in the RICO statute, including the offence of trafficking.' See Lan Cao, Illegal Traffic in Women: A Civil RICO proposal, 96 Yale L.J 1297 (1986-1987), 1297-1322, at1307.

2 OSCE, ODIHR, Trafficking in Human Beings: Implications for the OSCE, Background Paper, 1999/3, found on: www.osce.org/odihr/documents/background/ytafficking.htm, visited: 13.07.2003.
} 


\section{TRAFFICKING IN WOMEN AS VIOLATION OF HUMAN RIGHTS}

Even though men and boys are trafficked too, the majority of trafficked people in the world consist of women and girls, who are mostly trafficked for purposes of sexual exploitation. ${ }^{3}$ It could be said that trafficking in human beings is predominately gender-based influenced practice.

The phenomenon of trafficking in women has affected every country in the world, poor or rich. The countries of origin of women victims of trafficking generally are poor countries. The countries of transit usually en route to the destination countries are often countries that have weaker border control rules and are generally poor countries or countries in transition. ${ }^{4}$ The destination countries generally are countries, which are economically advanced and have significant demand for the prostitution per se, i.e. exploitation of the prostitution of women, and have weaker laws and/or lack of implementation of laws criminalizing traffickers.

Once women fall into the hands of traffickers, their future is bleak. The exploitation of these women usually starts as soon as they enter the process of transit. Their passports are taken away; their freedom of movement is restricted; they are subjected to psychological and physical ill treatment and torture, such as biting, rape, humiliation, deprivation of food and beverages etc. ${ }^{5}$ Upon reaching the countries of destination, the victims are often sold to brothel owners, debt bonded, and subjected to various forms of ill treatment and torture such as continuous rape by customers or pimps, and their associates, ${ }^{6}$ beaten upon refusal to fulfill orders or threatened with their life or the life of loved ones. In some cases, victims are killed, if they escape or have been disobedient (to set an example to other victims of trafficking). They are exposed to HIV and AIDS infections, ${ }^{7}$ are forced to abort in unsanitary conditions thus denied access to medical services, resulting in their deaths. ${ }^{8}$ Their freedom of movement is often strongly restricted and in some cases is non-existent. Making the picture even more horrendous is the fact that, in many societies government officials are involved in the exploitation of women and girls, either through active participation or through concurrence. In

\footnotetext{
${ }^{3}$ CIA estimates that approximately two percent of the trafficked persons within the OSCE region for forced prostitution are men and boys. See OSCE, ODIHR, Trafficking in Human Beings: Implications for OSCE, 1999. Also see USAID, The Emerging Global Market in Trafficking, Gender Matters Quarterly No.1, February 1999.

${ }^{4}$ United Nations, Economic Commission for Europe, Trafficking in Women and Girls, note prepared by the office of the High Commissioner for Human Rights and the ECE secretariat, UN Doc. E/ECE/RW.2/2000/3, 1 December 1999, pg. 5, par. 11.

5 Integration of the Human Rights of Women and the Gender Perspective, Report of the Special Rapporteur on violence against women, its causes and consequences, Ms. Radhika Coomaraswamy, on trafficking in women, women's migration and violence against women, submitted in accordance with Commission on Human Rights resolution 1997/44. Economic and Social Council, Doc. Num. E/CN.4/2000/68, 29 February 2000, pg. 6. Available at the web-site of the United Nations High Commissioner for Human Rights at:

http://www.unhcr.ch/html/menu2/7/b/mwom.htm.

${ }^{6}$ David Weissbrodt and Anti-Slavery International, Abolishing Slavery and its Contemporary Forms, United Nations High Commissioner for Human Rights, 2002, pg. 31.

7 The Health Risks and Consequences of Trafficking in Women and Adolescents, report by Zimmerman, C., Yun, K., Shvab, I., Watts, C., Trappolin, L., Treppete, M., Bimbi, F., Adams, B., Jiraporn, S., Beci, L., Albrecht, M., Bindel, J., Regan, L. (2003), London: London School of Hygiene \& Tropical Medicine (LSHTM), at 46.

8 Integration of the Human Rights of Women and the Gender Perspective, Report of the Special Rapporteur on violence against women, its causes and consequences, Ms. Radhika Coomaraswamy, on trafficking in women, women's migration and violence against women, submitted in accordance with Commission on Human Rights resolution 1997/44. Economic and Social Council, Doc. No. E/CN.4/2000/68, 29 February 2000, pg.6. Available at the web-site of the United Nations High Commissioner for Human Rights at:

http://www.unhcr.ch/html/menu2/7/b/mwom.htm.
} 
either instance, they fuel the practice. ${ }^{9}$ Thus, trafficking in human beings presents a myriad of human rights violations of the victims of trafficking, from the right to life to the right of liberty and security of person and freedom to be free from torture and degrading and inhuman punishment and freedom from slavery, forced labor and slavery like practices. ${ }^{10}$

Even though national and international efforts are made and some victims of trafficking are rescued, this rescue is usually a relative one depending on national laws and policies in relation to 'recognized victims of trafficking,' the existence of an adequate implementation mechanisms, attitudes towards victims of trafficking in the country where the victim is rescued and finally, the successful prosecution of perpetrators.

\section{PROSECUTION AS A PRECONDITION FOR SUCCESSFUL COMBAT OF TRAFFICKING IN WOMEN}

Successful prosecution of traffickers is a conditiosine qua non for the effective combat against trafficking in women. Without a successful prosecution the organized crime networks that profit from the trafficking in women are just left to grow and expand their horrendous illegal deeds. However, prosecution of traffickers is often a difficult task. The reasons range from high cost and recourse intensive investigations of cases of trafficking in human beings for the police and prosecution, to inaction on the part of police and prosecution related to inadequate laws and corruption issues. Inadequate laws usually have to do with poor definition of trafficking in women, failure to identify trafficked women as victims and/or to effectively protect women victims in the process of investigation and prosecution thus losing the only witnesses to this heinous crime.

\section{Basic steps needed in order to achieve better prosecution of traffickers}

In order to achieve an effective prosecution of trafficking in women it is important to note that in the process of enacting laws to fight trafficking in women one has to take into consideration the human rights of the victims of trafficking. Especially, this is important during the prosecution phase. ${ }^{11}$ When creating laws and measures concerned with this phase, it is important to take into account also the gender moment and to be in line with international legal documents, the human right ones and the more specific once dealing with trafficking in human beings. For example, the ECHR proscribes for protection of variety of human rights that are already being violated in the process of trafficking including jurisprudence that stresses the state obligation to protect victims of violation of human rights, as well as, the CoE's Convention on action against trafficking in human beings and the Palermo Protocol.

The CoE's Convention explicitly stipulates that the States Parties have to take into gender equality account the in applying measures:

'Article 17 - Gender equality

Each Party shall, in applying measures referred to in this chapter, aim to promote gender equality and use gender mainstreaming in the development, implementation and assessment of the measures. ${ }^{\prime 2}$

\footnotetext{
${ }^{9}$ See Linda Smith and Mohamed Mattar, Creating International Consensus on Combating Trafficking in Persons: US Policy, The Role of the UN, and the Global Responses and Challenges, The Fletcher Forum of World Affairs, Vol.28: I Winter 2004, pp. 156-178, at 160.

10 Ibid.

11 Vanessa Von Struensee, Globalized, Wired, Sex Trafficking In Women And Children, Murdoch University Electronic Journal of Law, Volume 7, Number 2 (June 2000).

12 Council of Europe Convention on Action against Trafficking in Human Beings and its Explanatory Report Warsaw, 16.V.2005, Council of Europe Treaty Series - No. 197, http://www.coe.int/trafficking
} 
Additionally, the EU Directive 2011/36/EU of the European Parliament and of the Council of 2011 on preventing and combating trafficking in human beings and protecting its victims (the Directive 2011/36/EU), ${ }^{13}$ foresees that the assistance and also support measures provided to victims of trafficking should be gender-specific. ${ }^{14}$ The Directive 2011/36/EU also acknowledges that trafficking is a gender-specific phenomenon. ${ }^{15}$

There are four basic steps into the prosecution of trafficking in women.On a national level, this would mean firstly, criminalizing the practice of trafficking in women by creating relevant criminal law legislation that will create legal duties for governments with respect to trafficking in women. Consequently, criminal law legislation should include trafficking in women as a distinct offence. Countries that have not included in their criminal law a distinct offence of trafficking should do so. ${ }^{16}$ In other cases trafficking is usually prosecuted under other existing laws (illegal migration, prostitution and pimping- all carrying small punishments) or it is not prosecuted at all. ${ }^{17}$ Secondly, it is important to define trafficking in women properly in national laws on trafficking. This is the basis for adequate application of those laws.

Thirdly, new anti-trafficking legislation should be designed as to detail adequate legal sanctions for the perpetrators (not mild punishments) and to be able to establish criminal liability of all actors involved in trafficking.

And fourthly a criminal liability for all actors involved in the practice of trafficking (with exception of victims) has to be established though proper investigation and prosecution.

The Protocol to Prevent, Suppress and Punish Trafficking in Persons, Especially Women and Children in its Article $5^{18}$ criminalizes trafficking as:

'Article 5

Criminalization

1. Each State Party shall adopt such legislative and other measures as may be necessary to establish as criminal offences the conduct set forth in article 3 of this Protocol, when committed intentionally.

2. Each State Party shall also adopt such legislative and other measures as may be necessary to establish as criminal offences:

(a) Subject to the basic concepts of its legal system, attempting to commit an offence established in accordance with paragraph 1 of this article;

(b) Participating as an accomplice in an offence established in accordance with paragraph 1 of this article; and

(c) Organizing or directing other persons to commit an offence established in accordance with paragraph 1 of this article.'

\footnotetext{
13 EU Directive 2011/36/EU of the European Parliament and of the Council of 2011 on preventing and combating trafficking in human beings and protecting its victims, and replacing Council Framework Decision 2002/629/JHA. Available at http://eur-lex.europa.eu/legal-content/en/TXT/?uri=CELEX\%3A32011L0036

14 Ibid, paragraph 3.

15 Ibid, paragraph 3.

${ }^{16}$ Angelika Kartuch, Reference Guide for Anti-Trafficking legislative review, OSCE ODIHR, 2001, at 41.

17 Ibid at 41.

18 Article 5, Protocol to Prevent, Suppress and Punish Trafficking in Persons, Especially Women and Children, found on:

www.uncjin.org/Documents/Conventions/dcatoc/final_documents.pdf, visited on 03.10.2004.
} 
The CoE's Convention also calls for criminalization of the practice of trafficking, but only when committed internationally:

'Article 18 - Criminalisation of trafficking in human beings

Each Party shall adopt such legislative and other measures as may be necessary to establish as criminal offences the conduct contained in article 4 of this Convention, when committed intentionally.' ${ }^{\prime} 9$

The Organisation for Security and Cooperation Action Plan in a similar way stresses the need for criminalization of the practice of trafficking on a national level, thus recognizing it as a separate offence under domestic criminal law. It also recognizes the need for a clear definition of trafficking and supports the one offered by the Protocol in Article 3.20The Action Plan calls for:

'Adopting such legislative and other measures as may be necessary to establish as criminal offences the conduct set forth in Article 3 of the United Nations Protocol to Prevent, Suppress and Punish Trafficking in Persons, especially Women and Children, supplementing the United Nations Convention against Transnational Organized Crime.

1.2 Adopting such legislative and other measures as may be necessary to establish as criminal offences:

- Attempting to commit this criminal offence;

- Participating as an accomplice in this criminal offence;

- Organizing or directing other persons to commit this criminal offence. ${ }^{21}$

When looking at the European Court of Human Rights (ECtHR) case law and making a connection to criminalization of trafficking and adopting relevant legislation pursuant to it, the case of $X$ and $Y v$. The Netherlands, ${ }^{22}$ has identified positive State obligations in the judgment when the Court held that there was an obligation on the state to adopt criminal law provisions to secure the effective protection of individuals. Culpable state failure to act on this obligation could give rise to a violation of the ECHR. Moreover, in the case Young, James and Webster v. The United Kingdom ${ }^{23}$ the Court stated that "Under Article 1 of the Convention, each Contracting State 'shall secure to everyone within [its] jurisdiction the rights and freedoms defined in ... [the] Convention,' meaning that if a violation of one of those rights and freedoms is the result of non-observance of that obligation in the enactment of domestic legislation, the responsibility of the State for that violation is engaged. ${ }^{24}$ More recently the Court in a landmark decision, confirmed that trafficking in human beings, although not explicitly mentioned in the ECHR, fell within the scope of Article 4 (prohibition of slavery, servitude and forced labour). This followed the case of Siliadin v. France ${ }^{25}$ which judgment focused only the failing criminal law framework in place at the time.

\footnotetext{
${ }^{19}$ Article 18, Council of Europe Convention on Action against Trafficking in Human Beings and its Explanatory Report Warsaw, 16.V.2005, Council of Europe Treaty Series - No. 197, http://www.coe.int/trafficking 20 Decision No. 557 OSCE Action Plan to Combat Trafficking in Human Beings, PC.DEC/557, 24 July 2003. See Chapter II for definition of trafficking.

${ }^{21}$ Ibid, paragraph. 1.1., 1.2.

${ }^{22}$ Eur. Court HR, X and Y v. The Netherlands judgment of 26 March 1985, Series A no. 91, paragraph 23

${ }^{23}$ Eur. Court HR, Young James and Websters v. The United Kingdom, judgment of 13 August 1981, Series A, no. 44, paragraph 49.

${ }^{24}$ Council of Europe Convention on Action against Trafficking in Human Beings and its Explanatory Report Warsaw, 16.V.2005, Council of Europe Treaty Series - No. 197, http://www.coe.int/trafficking

25 Siliadin v. France (Appl.no. 73316/01) of 2005.
} 
In the most current case of Rantsev v. Cyprus and Russia, the Court took a much more thorough look at the whole issue of trafficking and clarified the obligations of states in this respect, addressing criminalization of trafficking and protection of the victims. ${ }^{26}$ If the authorities are aware of a situation of human trafficking or of the real risk that an individual will get into such a situation, it is obliged to take appropriate measures. This includes a procedural obligation to investigate situations of potential human trafficking and to cooperate with the investigations of other state parties.

These international standards translated into possible actions with respect to sanctions against trafficking, harsh penalties have to be introduced to serve as a deterrent to potential traffickers and their accomplices. These penalties have to include the mechanism of aggravating circumstances' with respect to the intensity of cruelty of the respective criminal deed:

'Making legislative provisions for effective and proportionate criminal penalties, including imprisonment, that take into account the serious nature of this crime. Where appropriate, legislation should provide for additional penalties to be applied to persons found guilty of trafficking in aggravating circumstances, such as in the case of offences involving trafficking in children or offences committed by or involving the complicity of State officials. ${ }^{27}$

The CoE' Convention provides for the following aggravating circumstances:

'Article 24 requires Parties to ensure that certain circumstances...are regarded as aggravating circumstances in the determination of the penalty for offences established in accordance with Article 18 of this Convention.

The first of the aggravating circumstances is where the trafficking endangered the victim's life deliberately or by gross negligence. This aggravating circumstance is likewise laid down in Article 3(2) of the European Union Council Framework Decision of 19 July 2002 on combating trafficking inhuman beings. The circumstance arises, for example, where the conditions in which trafficking victims are transported are so bad as to endanger their lives.

The second aggravating circumstance is where the offence was committed against a child -that is, for the purposes of the Convention, against a person aged under 18.28

Including government officials, as a liable party should be a priority. The different levels of involvement as a qualification of the gravity of the offence must be recognized. With respect to the State responsibility towards participation of government officials in the process of trafficking of human beings, a criminal, civil or administrative liability has to be established by adopting special legislation, as stated by the ECtHR in $Z$ and others $v$. the United Kingdom. ${ }^{29}$

The CoE's Convention sees the involvement of public officialsas a third aggravating circumstance:

\footnotetext{
${ }^{26}$ Rantsev vs Cyprus and Russia, judgment of 7 January 2010. Available at http://www.echr.coe.int/Documents/FS_Trafficking_ENG.pdf

27 Decision No. 557 OSCE Action Plan to Combat Trafficking in Human Beings, PC.DEC/557, 24 July 2003, para. 1.4.

${ }^{28}$ Article 24, Council of Europe Convention on Action against Trafficking in Human Beings and its Explanatory

Report Warsaw, 16.V.2005, Council of Europe Treaty Series - No. 197, http://www.coe.int/trafficking.

${ }^{29} \mathrm{Z}$ and others IV. the United Kingdom, 29392/95 [2001] ECHR 333 (10 May 2001).
} 
The third aggravating circumstance is where the trafficking was committed by a public official in the performance of his or her duties. ${ }^{30}$

The OSCE Action Plan stresses the importance of:

Adopting such measures as may be necessary to establish the liability of legal persons for trafficking offences in addition to the liability of natural persons. Subject to the legal principles of the participating State, the liability of legal persons may be criminal, civil and/or administrative. ${ }^{31}$

Anti-trafficking legislation should also provide for the creation of special task force to combat trafficking in women. This task force will deal with investigation of trafficking and the victims of trafficking in the investigation period of the prosecution, ${ }^{32}$ possibly in a form of organized crime department.

States should interpret and amend existing provisions of the law punishing slavery and unlawful depravations of liberty. In that way, they will ensure that the law will prohibit situations in which the right to be free from slavery and the right to security and liberty of person of the trafficking victims can be violated. The ECtHR in the case of Pantea $v$ Romania 33 found in connection of the depravation of liberty and the conditions of detention the States has an obligation to protect all persons under its supervision including protection from the actions of private individuals. Also, the ICCPR HR Committee has stipulated that the States have a duty to investigate murders of victims of trafficking that can be regarded as a positive State obligation to investigate and prevent killings by non-state actors as well as by State actors. $^{34}$

An important step in the process of punishing slavery and servitude is making sure that clearly identifiable and provable elements of psychological coercion are recognized as method of constraint, ${ }^{35}$ as pointed out by the ECtHR in $W, X, Y$, and $Z v$ United Kingdom. ${ }^{36}$ Furthermore, the States should apply existing slavery provisions to cover modern forms of slavery such as trafficking and to make sure that they are consistent with the anti-trafficking provisions, adopted under the Protocol.

\section{Secondary steps}

After the basic steps are met, a secondary level of two conditions has to be met in order to successfully prosecute the traffickers.

\footnotetext{
${ }^{30}$ Article 24, Council of Europe Convention on Action against Trafficking in Human Beings and its Explanatory Report Warsaw, 16.V.2005, Council of Europe Treaty Series - No. 197, http://www.coe.int/trafficking.

31 Decision No. 557 OSCE Action Plan to Combat Trafficking in Human Beings, PC.DEC/557, 24 July 2003, para. 1.3 .

32 For example, in Columbia in 1996, a law was adopted to create an Interagency Committee against trafficking in women and children. ${ }^{32}$ The Committee includes representatives of the Ministry of Justice, the Ministry of Foreign Relations, the General Department of Security, the Attorney General's Office, the General Director of the National Police, the Ombudsman, the Office of Civil Registration, the Program of the President for personal freedom, the Colombian Institute of Family, the Office of Women Equity, INTERPOL, and the Child Office. ${ }^{32}$ There is a special trafficking unit within the police for investigating trafficking cases; United Nations Division for the Advancement of Women (DAW) and the United nations Office on Drugs and crime (ODC), Trafficking in Women and Girls, Report of the Expert Group Meeting, Glen Cove, New York, USA, 18-22 November 2002, Doc. No. EGM/TRAF/2002/rep.1. 33 Pantea v Romania, 33343/96 [2003] ECHR 266 (3 June 2003). Available at https://hudoc.echr.coe.int/eng\#\{"documentcollectionid2":["GRANDCHAMBER","CHAMBER"]\}

34 Concluding Observations of the Human Rights Committee, Lesotho, UN Doc. CCPR/C/79/Add.106 (1999).

${ }^{35}$ Anti-Slavery International, Human Traffic, human rights: redefining victim protection, by Elaine Pearson, 2002.

${ }^{36}$ Cited in Clare Ovey \& Robin C.A. White, European Convention on Human Rights, third edition, 2002 , at 91.
} 
One refers to the rights of women victims of trafficking during the prosecution process. This is closely connected to the active participation of the victims in the process of collecting evidence and the actual prosecution. The other condition refers to the ability of the investigation and prosecution unit.

The relevance of the first condition to the successful combat of trafficking in women in part overlaps with the relevance of active protection of the victims of trafficking. The second condition has to be achieved through training programs for investigation units and prosecutors with special attention on the human rights of the victims of trafficking and the fragility of their condition after being rescued. ${ }^{37}$ This is also related to cooperation between governments encompassing police enforcement agencies, and the judiciary by creating joint task forces, exchanging information, and extradition of offenders. ${ }^{38}$

The author will briefly enumerate the condition referring to the rights of the women victims of trafficking during the prosecution process that is closely connected to the active participation of the victims in the process of collecting evidence and the actual prosecution. It is at this point that the human rights approach reaches its maximum in the prosecution stage. The realization of this condition depends on the four measures that have to be enacted and implemented into the Criminal Procedure codes of the respective countries. The first two measures are:

1. Speedy and considerate police questioning of victims of trafficking, with presence of translators, and process of referral of victims of trafficking to protection centers. ${ }^{39}$

2. Victims of trafficking to receive legal aid in the pre trial investigative procedure and to be in position to give officially on record statements.

This strategy obliges state to provide in its internal law for the right to legal assistance and free legal aid for victims under the conditions provided by its internal law. Since court and administrative procedure is often very complex, legal assistance is necessary for victims to be able to claim their rights. States must have regard for Article 6 of the ECHR. Article 6(3)(c) of the ECHR provides for free assistance from an officially appointed lawyer only in criminal proceedings, which are often very crucial in trafficking cases. However, European Court of Human Rights case-law, as in Airey v. Ireland ${ }^{40}$ also recognizes, in certain circumstances, the right to free legal assistance in a civil matter on the basis of Article 6(1) ECHR, interpreted as establishing the right to a court for determination of civil rights and obligations as said by the ECtHR in Golder v. the United Kingdom. ${ }^{41}$

The second two measures are:

3. Protecting the right to privacy of the victims of trafficking during trials, avoiding degrading and humiliating treatment of the victims of trafficking during trials.

4. Protecting the right to be free from torture and degrading and inhuman treatment, the right to privacy and possibly the right to life, by initiating the practice of providing testimonies of the victims of trafficking through a video link.

\footnotetext{
37 United Nations Division for the Advancement of Women (DAW) and the United nations Office on Drugs and crime (ODC), Trafficking in Women and Girls, Report of the Expert Group Meeting, Glen Cove, New York, USA, 1822 November 2002, Doc. No. EGM/TRAF/2002/rep.1.

38 Decision No. 557 OSCE Action Plan to Combat Trafficking in Human Beings, PC.DEC/557, 24 July 2003, para. 1.3.

${ }^{39}$ Vladimir Danailov and Sterijo Zikov, Towards the Handbook for the Public Prosecutors in Prosecution of the Human Trafficking Crime, IOM, Mission in Skopje, with cooperation of the Association of public prosecutors in the republic of Macedonia, 2005.

${ }^{40}$ Airey v. Ireland,- 6289/73 [1979] ECHR 3 (9 October 1979).

${ }^{41}$ Golder v. the United Kingdom, 4451/70 [1975] ECHR 1 (21 February 1975).
} 
This means that procedural legislation should be enacted or amended to protect victim's right to privacy during trials against traffickers. The HR Committee's General Comment 16 has pointed out at the positive obligation of the State to safeguard one's right to privacy: ${ }^{42}$

'In the view of the Committee this right is required to be guaranteed against all such interferences and attacks whether they emanate from State authorities or from natural or legal persons. The obligations imposed by this article require the State to adopt legislative and other measures to give effect to the prohibition against such interferences and attacks as well as to the protection of this right.'

Actions such as death threats, threats of rape, various humiliating acts and threats of reprisals against a detainee's family may all constitute mental suffering for the purposes of Article 3 as well as, found by the Court in Sevtap Veznedaroglu $v$ Turkey. ${ }^{43}$ Accordingly, the state has a positive obligation to prevent any such acts or to investigate and punish perpetrators.

\section{CONCLUSION}

The key in effective combating of trafficking in women must be supported with enacted legislation that covers this heinous crime form all perspective and gives a sound basis for future prosecution of traffickers. However, it is important to have in mind that this is not possible without taking into consideration the gender moment in enacting legislation, and the human rights of the victims. As argued above, without a gender perspective in legal and policy changes within countries, the requirements of the international human rights law and effective prosecution may be denied to the victims.

\section{References}

Angelika Kartuch, Reference Guide for Anti-Trafficking legislative review, OSCE ODIHR, 2001

Clare Ovey \& Robin C.A. White, European Convention on Human Rights, third edition, 2002

David Weissbrodt and Anti-Slavery International, Abolishing Slavery and its Contemporary Forms, United Nations High Commissioner for Human Rights, 2002

Lan Cao, Illegal Traffic in Women: A Civil RICO proposal, 96 Yale L.J 1297 (1986-1987), 1297-1322

Linda Smith and Mohamed Mattar, Creating International Consensus on Combating Trafficking in Persons: US

Policy, The Role of the UN, and the Global Responses and Challenges, The Fletcher Forum of World Affairs, Vol.28: I Winter 2004

Health Risks and Consequences of Trafficking in Women and Adolescents, report by Zimmerman, C., Yun, K., Shvab, I., Watts, C., Trappolin, L., Treppete, M., Bimbi, F., Adams, B., Jiraporn, S., Beci, L., Albrecht, M., Bindel, J., Regan, L. (2003), London: London School of Hygiene \& Tropical Medicine (LSHTM), Website resources:

Vanessa Von Struensee, Globalized, Wired, Sex Trafficking In Women And Children, Murdoch University Electronic Journal of Law, Volume 7, Number 2 (June 2000)

Vladimir Danailov and Sterijo Zikov, Towards the Handbook for the Public Prosecutors in Prosecution of the Human Trafficking Crime, IOM, Mission in Skopje, with cooperation of the Association of public prosecutors in the republic of Macedonia, 2005

\section{ECtHR Case Law}

Eur. Court HR, X and Y v. The Netherlands judgment of 26 March 1985, Series A no. 91

Eur. Court HR, Young James and Websters v. The United Kingdom, judgment of 13 August 1981, Series A, no. 44

Eur.Court HR,_Siliadin v. France (Appl.no. 73316/01) of 2005.

\footnotetext{
${ }^{42}$ HR Committee's General Comment 16.

43 Sevtap Veznedaroglu v Turkey 32357/96 [2000] ECHR 167 (11 April 2000).
} 
Eur. Court HR, Rantsev vs Cyprus and Russia, judgment of 7 January 2010. Available at http://www.echr.coe.int/Documents/FS_Trafficking_ENG.pdf

Eur. Court HR, Z and others IV. the United Kingdom, 29392/95 [2001] ECHR 333 (10 May 2001)

Eur. Court HR, Pantea v Romania, 33343/96 [2003] ECHR 266 (3 June 2003). Available at https://hudoc.echr.coe.int/eng\#\{"documentcollectionid2":["GRANDCHAMBER","CHAMBER"]\}

Eur. Court HR, Airey v. Ireland,- 6289/73 [1979] ECHR 3 (9 October 1979).

Eur. Court HR, Golder v. the United Kingdom, 4451/70 [1975] ECHR 1 (21 February 1975)

Eur. Court HR, Sevtap Veznedaroglu v Turkey 32357/96 [2000] ECHR 167 (11 April 2000

\section{Other resources}

Anti-Slavery International, Human Traffic, human rights: redefining victim protection, by Elaine Pearson, 2002

Council of Europe Convention on Action against Trafficking in Human Beings and its Explanatory Report Warsaw, 16.V.2005, Council of Europe Treaty Series - No. 197, http://www.coe.int/trafficking

Concluding Observations of the Human Rights Committee, Lesotho, UN Doc. CCPR/C/79/Add.106 (1999).

Decision No. 557 OSCE Action Plan to Combat Trafficking in Human Beings, PC.DEC/557, 24 July 2003

EU Directive 2011/36/EU of the European Parliament and of the Council of 2011 on preventing and combating trafficking in human beings and protecting its victims, and replacing Council Framework Decision 2002/629/JHA. Available at http://eur-lex.europa.eu/legal-content/en/TXT/?uri=CELEX\%3A32011L0036

OSCE, ODIHR, Trafficking in Human Beings: Implications for the OSCE, Background Paper, 1999/3, found on: www.osce.org/odihr/documents/background/ytafficking.htm

United Nations, Economic Commission for Europe, Trafficking in Women and Girls, note prepared by the office of the High Commissioner for Human Rights and the ECE secretariat, UN Doc. E/ECE/RW.2/2000/3, 1 December 1999

United Nations Protocol to Prevent, Suppress and Punish Trafficking in Persons, Especially Women and Children, found on: www.uncjin.org/Documents/Conventions/dcatoc/final_documents.pdf

United Nations Division for the Advancement of Women (DAW) and the United nations Office on Drugs and crime (ODC), Trafficking in Women and Girls, Report of the Expert Group Meeting, Glen Cove, New York, USA, 18-22 November 2002, Doc. No. EGM/TRAF/2002/rep.1

USAID, The Emerging Global Market in Trafficking, Gender Matters Quarterly No.1, February 1999 